\title{
Phytochemical characterization, antioxidant potential and antibacterial activity of the Croton argyrophylloides Muell. Arg. (Euphorbiaceae)
}

\author{
Caracterização fitoquímica, potencial antioxidante e atividade antibacteriana do \\ Croton argyrophylloides Muell. Arg. (Euphorbiaceae)
} \author{
A. F. Santos ${ }^{\mathrm{a}, \mathrm{e}}$ (1) and S. A. Fonseca ${ }^{\mathrm{a} *}$ (1) \\ aCentro Universitário Cesmac, Maceió, AL, Brasil \\ bUniversidade Federal de Alagoas - UFAL, Maceió, AL, Brasil \\ Instituto Federal de Educação, Ciência e Tecnologia do Acre - IFAC, Xapuri, AC, Brasil \\ 'Universidade Estadual de Ciências da Saúde de Alagoas - UNCISAL, Maceió, AL, Brasil \\ eUniversidade Estadual de Alagoas - UNEAL, Arapiraca, AL, Brasil
}

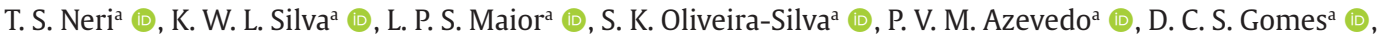

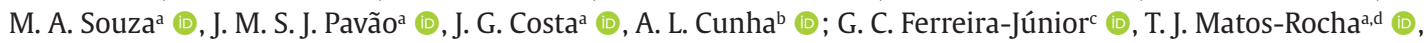

\begin{abstract}
Croton argyrophylloides Muell. Arg., from the Euphorbiaceae family, popularly known as marmeleiro prateado or sacatinga, is a plant from the Caatinga biome commonly found in Brazil's northeastern region. The present study aimed to evaluate the antioxidant activity of the species. The phytochemical study was performed through qualitative analysis of chemical constituents and quantitative determination of the total phenol content through the Folin-Ciocalteu test. The qualitative and quantitative antioxidant tests were performed using the DPPH method (2.2 diphenyl-1-picryl hydrazil) and ferric reducing antioxidant power (FRAP). The minimum inhibitory concentration (MIC) was determined by microdilution in 96-well plates. The ethanolic extract of the leaves of $C$. argyrophylloides manifested antioxidant action in the quantitative DPPH test with a significant bioactivity of $84.70 \mathrm{AAO} \%$ in $500 \mu \mathrm{g} / \mathrm{mL}$, with an $\mathrm{EC}_{50}$ of 236.79 . The content of total phenolic compounds was $946.06 \mathrm{mg}$ of gallic acid equivalents $/ \mathrm{g}$ of sample, and total flavonoids was $58.11 \mathrm{mg}$ of quercetin equivalents/g of sample, the result obtained for FRAP was $15294.44 \mu \mathrm{M}$ Trolox/g of sample and ABTS was $718 \mu \mathrm{M}$ Trolox of sample. The prospecting of the chemical constituents of the leaves of $C$. argyrophylloides revealed the presence of the main compounds that manifests the antioxidant activity and it was proven by the DPPH method that there is antioxidant activity in the analyzed sample, in addition to demonstrating a significant content of phenolic compounds and total flavonoid content in the species, which corroborates the antioxidant activity of the plant sample. The leaf extracts presented growth inhibition halos of 10 and $12 \mathrm{~mm}$ upon Staphylococcus aureus ATCC 25923.
\end{abstract}

Keywords: Croton argyrophylloides Muell. Arg, antioxidant, phytochemistry, minimal inhibitory concentration.

\begin{abstract}
Resumo
Croton argyrophylloides Muell. Arg., pertencente à família Euphorbiaceae, conhecida popularmente como marmeleiro prateado e sacatinga, é um vegetal do bioma caatinga comumente encontrado no Nordeste do Brasil. O presente trabalho teve como objetivo avaliar a atividade antioxidante da espécie. 0 estudo fitoquímico foi realizado por meio de análise qualitativa dos constituintes químicos e determinação quantitativa do teor de fenóis totais pelo teste de Folin-Ciocalteu. Os testes antioxidantes qualitativos e quantitativos foram realizados pelo método do $\mathrm{DPPH}$ (2,2 difenil-1- picril-hidrazila)e redução do ferro (FRAP). A concentração inibitória mínima (CIM) foi determinada por microdiluição em placas de 96 poços. O extrato etanólico das folhas de $C$. argyrophylloides apresentou ação antioxidante no teste DPPH quantitativo com uma significativa bioatividade de $84.70 \mathrm{AAO} \%$ em $500 \mu \mathrm{g} / \mathrm{mL}$, apresentando um $\mathrm{CE}_{50}$ de 236.79 . O teor de compostos fenólicos totais, foi de 946,06 mg equivalentes de ácido gálico/g de amostra, e de flavonoides totais de 58,11 mg equivalentes de quercetina/g da amostra, o valor encontrado para FRAP foi de 15294,44 $\mu \mathrm{M}$ Trolox/g da amostra e de ABTS foi $718 \mu \mathrm{M}$ Trolox da amostra. A prospecção dos constituintes químicos das folhas de $C$. argyrophylloides revelou a presença dos principais compostos que caracterizam a atividade antioxidante e foi possível comprovar pelo método de DPPH que há atividade antioxidante na amostra analisada, além de demonstrar um resultado significativo de teor de compostos fenólicos e teor de flavonoides totais na espécie e o que corrobora com a atividade antioxidante da amostra vegetal. Os extratos das folhas apresentaram halos de inibição de crescimento de 10 e 12mm frente a Staphylococcus aureus ATCC 25923.
\end{abstract}

Palavras-chave: Croton argyrophylloides Muell Arg, antioxidante, fitoquímica, concentração mínima inibitória.

*e-mail: saskya_mcz@hotmail.com

Received: April 15, 2020 - Accepted: June 16, 2021 


\section{Introduction}

Antioxidants may be defined as substances capable of retarding or inhibiting oxidation of oxidizable substrates, which may be enzymatic or non-enzymatic, such as $\alpha$-tocopherol-vitamin E, $\beta$-carotene, ascorbic acid-vitamin C and the phenolic compounds (Alam et al., 2013). In humans, the synthesis of free radicals can be controlled by antioxidants, which can be from endogenous origin or from the diet, among other sources (Sehwag and Das, 2014).

Silva et al. (2012) reports that the significance of antioxidants, concerning free radical effects, lies on the increase of oxygen-reactive species and/or decline of antioxidant cellular activity, hence causing oxidative stress, possibly injuring different molecules. Antioxidants have biological properties similar to phenolic compounds, once they are able to "hijack" free radicals due to its characteristic of being electron donors.

Oxidative stress, induced by free radicals, is responsible for several chronic diseases, including: diabetes, Parkinson's and Alzheimer's disease, multiple sclerosis, muscular dystrophy, cataracts and retinopathies, atherosclerosis, myocardial infarction, liver cirrhosis and different types of cancer (Speisky et al., 2012).

Another major public health issue are humaninfecting bacteria, which have been widely studied due to its pathogenicity: Staphylococcus aureus, Pseudomonas aeruginosa and Escherichia coli, which is also part of natural human microbiota, and may cause opportunistic infections by penetrating unusual sites or through pathogenic serotypes (Cramer and Coleus, 2016). Hence, researching new synthetic and vegetal-origined antibacterial compounds is relevant. More than 5.000 phytochemicals have been identified, however, a large percentage of these remain unknown and their identification is revelant to better understanding their health contribution when included in human diet (Floegel et al., 2011).

Phytochemicals include carotenoids ( $\alpha$-carotene, $\beta$-carotene, $\beta$-cryptoxanthin, lutein, zeaxanthin, astaxanthin and lycopene); phenolic compounds: phenolic acids (hydroxybenzoic acids and hydroxycinnamic acids), flavonoids (flavonols, flavones, flavanols, flavanones, anthocyanidins and isoflavonoids), stybenes, coumarins and tannins; alkaloids; nitrogen compounds (derivatives of chlorophyll, amino acids and amines) and: (isothiocyanates, indoles, allylic sulfur compounds) (Halliwell and Gutteridge, 2015). The most studied phytochemicals are phenolic compounds and carotenoids. Plant species that have significant sources of phenolic compounds express antioxidant potential (Silva et al., 2012).

The caatinga's flora contain multiple plants with prominent pharmacological and economic potential (Silva and Freire, 2010). The Euphorbiaceae family has about 317 genera and 7,500 species. Croton is the second largest genus of Euphorbiaceae, with approximately 1,200 species distributed predominantly on the American continent. Brazil, with about 300 species, is one of the main centers of diversity of the genus, which is represented in the most varied environments and vegetation types (Berry et al., 2005). Croton argyrophylloides Muell is among the most applied species in traditional medicine.
Arg, from Euphorbiaceae family, popularly known in the Northeast region as "marmeleiro prateado" or "sacatinga" presents several medicinal properties such as antimicrobial, antiedematogenic, antinociceptive and antioxidant (Porto, 2010).

Due to this oxidative stress, it is necessary to study natural resources such as medicinal plants, which are primary commodities that can be used in the production of herbal medicines and other drugs. In this context, it is suitable to search for vegetable species that have antioxidant properties in order to prevent diseases and deep tissue damage. Therefore, the objective of this study was to perform phytochemical characterization, evaluate antioxidant potential and antibacterial properties of C. argyrophylloides, thus contributing to discovery of new bioactive molecules with medicinal properties.

\section{Material and Methods}

The present experimental analytical study (in vitro laboratory research) was performed in the multidisciplinary research laboratory of the Centro Universitário Cesmac and in the Natural Resources Research laboratory of the Universidade Federal de Alagoas (LPqRN).

\subsection{Plant material collection}

The leaves of $C$. argyrophylloides were collected in the Delmiro Gouveia city in 2015. The exsiccates were deposited at the Institute of the Environment of the State of Alagoas' Herbarium MAC, under registration number 4568; the identification was operated by the botanist responsible for the MAC Herbarium. The leaves were dried in an oven at $37^{\circ} \mathrm{C}$ and then crushed. The plants' powder was stored in a dark and hermetically sealed container.

\subsection{Obtaining the ethanolic extract}

The ethanolic extract from the leaves of $C$. argyrophylloides was prepared through the maceration method, blended with absolute ethanol for 72 hours, after which the extracts were filtered. This procedure was repeated until maximum extraction of the plant material. The liquid sample obtained was then subjected to concentration in a rotary evaporator under reduced pressure until the crude ethanolic extract was obtained (Silva et al., 2019).

\subsection{Phytochemical prospecting}

The phytochemical prospecting qualitative tests were based on the methodologies described by Matos (1997), performed to verify the presence of phenols, pyrogalic tannins, phobaphenic tannins, anthocyanin and anthocyanidin, flavones, flavonols, xanthones, chalcones, auronas, flavononols, leukanthocyanidins, flavonones, steroids, triterpenoids, saponins, anthocyanin heterosides and alkaloids.

\subsection{Quantitative antioxidant evaluation by the DPPH method}

The quantitative evaluation of the antioxidant activity performed with standard methodology, adapted for testing 
on microplates, monitoring the consumption of the free radical DPPH by the vegetable sample, by measuring the decrease in the absorbance of solutions with different concentrations (Brand-Willians et al., 1990; Sánchez, 2002). In order to evaluate the absorbance measurements in the vegetable sample, it was diluted, in quadruplicate, with $200,150,75,50,25$ and $12 \mu \mathrm{g} \cdot \mathrm{mL}^{-1}$ in ethanol, starting from the solution with $1.0 \mathrm{mg} \mathrm{mL}^{-1}$. $1.0 \mathrm{~mL}$ of $0.3 \mathrm{mM}$ DDPH in ethanol was added to $2.5 \mathrm{~mL}$ of the plant sample. The reactions occurred at room temperature (around $26^{\circ} \mathrm{C}$ ) for 30 minutes. The absorbance data were then analyzed at $518 \mathrm{~nm}$. The drink's antioxidant influence was calculated by the absorbance of the sampled solution with sample and DPPH, Abranco: the absorbance of the sampled solution without addition of DPPH and Acontrol: the absorbance of the reference solution DPPH and ethanol (Silva et al., 2019; Mensor et al., 2001).

\subsection{Calculating the $E C_{50}$}

$\mathrm{EC}_{50}$ 's (Concentration that induces half the maximum effect) calculation provides numerical parameters of how capable to produce antioxidant substances the vegetable sample is and also to verify its effectiveness against free radicals in the tested model. The values of $\mathrm{AAO} \%$ and concentrations $\left(200,150,75,50,25\right.$ and $\left.12 \mu \mathrm{g} \cdot \mathrm{mL}^{-1}\right)$ were correlated using the program "Excel for Windows", obtaining, the line equation for the plant. By solving this equation (replacing the $\mathrm{Y}$ value with 50 ) $\mathrm{EC}_{50}$ 's data was obtained, which is the concentration required to produce half ( $50 \%$ ) of a maximum effect estimated at $100 \%$ for the plant extract (Mensor et al., 2001).

\subsection{Phenolics compounds determination}

The content of phenolic compounds in the vegetable sample was obtained based on the Folin-Ciocalteau colorimetric method, with some modifications. The total phenol values were expressed as gallic acid equivalents (mg of gallic acid/ $\mathrm{g}$ of sample).

The Folin-Ciocalteu reagent is composed of a mixture of phosphomolybdic and phosphotunguistic acids, in which molybdenum and tungsten are in the $6^{+}$oxidation state. However, in the presence of some reducing agents, such as phenolic compounds, blue molybdenum and blue tungsten are formed, of which the average metal oxidation state varies between 5 and 6 and whose color allows the determination of the concentration of substance reducing agents, which do not necessarily need to be phenolic. The results were expressed in mg of gallic acid per g of dry sample weight (mg EAG/g). Determining total polyphenols by reacting with the Folin-Ciocalteau reagent is based on the principle that in an alkaline medium, phenols reduce the mixture of phosphotungstic and phosphomolybdic acids to blue tungsten and molybdenum oxides (Scherer and Godoy, 2014).

\subsection{Quantitative determination of flavonoids}

The sample was diluted to a concentration of $0.150 \mathrm{mg} / \mathrm{mL}$ in ethanol and to $2.0 \mathrm{~mL}$ of that solution, $1.0 \mathrm{~mL}$ of the $2 \%$ aluminum chloride reagent was added, a solution also diluted in ethanol. After 15 minutes, the samples were analyzed on a spectrophotometer at $420 \mathrm{~nm}$. In order to calculate the flavonoid content, a calibration curve using the quercetin standard was used, using the sample's absorbance data (Silva et al., 2018).

The aluminum cation forms stable complexes with the flavonoids in ethanol, causing a bathochromic shift in the electromagnetic spectrum in the UV-VIS region and increases absorption. In this way, it is possible to determine the amount of flavonoids, avoiding the interference of other phenolic substances, mainly phenolic acids, which invariably link to flavonoids in plant tissues. Phenolic acids, even those that form complexes with $\mathrm{AlCl}_{3}$, absorb at much shorter wavelengths, thereby avoiding interferences in absorbance measurements.

\subsection{ABTS free radical capture test [2,2-azino-bis (3-ethylbenzotazolin) -6-sulfonic]}

The antioxidant activity through the ABTS cation capture test was performed according to the methodology applied by Silva et al. (2018). The ABTS cation was obtained by reacting $7 \mathrm{mM}$ of the ABTS stock solution with $2.45 \mathrm{mM}$ of potassium persulfate. The mixture was stored in a dark bottle and at room temperature for 12-16 hours, before use. The ABTS solution was diluted with phosphate buffer ( $\mathrm{pH} 7.4$ ) to an absorbance of 0.7 to $730 \mathrm{~nm}$. After adding a $10 \mu \mathrm{L}$ sample or Trolox standard to $4 \mathrm{~mL}$ of diluted ABTS solution, absorbance data at $730 \mathrm{~nm}$ was gathered after 6 minutes of reaction. Ethanol solutions with known concentrations of Trolox $(100,200,500,1000$, 1500,2000 and $2500 \mu \mathrm{Mol} / \mathrm{L}$ ) were used for calibration. The results were expressed as Trolox equivalent Antioxidant Capacity (TEAC- $\mu \mathrm{Mol} / \mathrm{LTrolox} / \mu \mathrm{g} / \mathrm{mL}$ ).

\subsection{Ferric reducing antioxidant power - FRAP}

In order to evaluate antioxidant activity, $900 \mu \mathrm{L}$ of the FRAP reagent previously prepared was mixed with $90 \mu \mathrm{L}$ of distilled water and $10 \mu \mathrm{L}$ of the sample or standard. The samples were incubated at $37^{\circ} \mathrm{C}$ for 30 minutes and the reading was performed at $595 \mathrm{~nm}$. Standard solutions with different concentrations of Trolox $(10,100,200,300$, $400,500,600,700,800,900$ and $1000 \mu \mathrm{mol} / \mathrm{L})$ were used for calibration. The sample results will be expressed as

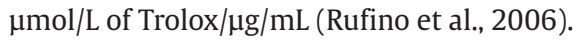

\subsection{Antibacterial activity evaluation}

Standard ATCC ${ }^{\circledR}$ strains acquired from Centrallab were used in the form of lyophilisates and added to the refrigerator, to be then dissolved in a liquid medium. The tested microorganisms were: Staphylococcus aureus ATCC 25923, Pseudomonas aeruginosa ATCC 27853, Escherichia coli ATCC 25922. The sizes of the halos were evaluated.

The microbial inoculum was prepared by removing some bacterial colonies from the pre-inoculation plates (and suspended in sterile saline solution $(0.9 \% \mathrm{NaCl})$ until the turbidity was adjusted to $0.5 \mathrm{Mac}$ Farland's 0.5 scale. By using tweezers and a watch glass, the filter paper discs were soaked directly in the crude ethanol extract in triplicates, right after being taken to the oven for 24 hours at a temperature of $35^{\circ} \mathrm{C}$. 
Sterile filter paper discs, previously impregnated in the crude extract, with a diameter of $6 \mathrm{~mm}$ were used. As a positive control, amikacin discs $(10 \mu \mathrm{g})$ from (Cecon $\left.{ }^{\circledR}\right)$ and chloramphenicol $(10 \mu \mathrm{g})$ from (Cecon $\left.{ }^{\circledR}\right)$ were used. The disks were impregnated with the extract and added on the surface of the culture medium that was previously sown with bacterial inoculum. The plates were inversely incubated at $37^{\circ} \mathrm{C}$ for 24 hours. The tests were performed in triplicates and the results were determined by the arithmetic mean of the diameter of the growth inhibition bacterial halos. Extracts with growth inhibition halos $\geq 8 \mathrm{~mm}$ in diameter were considered active for at least one of the strains tested (Catão et al., 2010). The Minimum inhibitory concentration was defined as the lowest concentration able to inhibit microbial growth. Statistical analyses were performed using the Assistat program (7.6). The variance analysis of the experiment was determined using the Dunnett test at the level of $5 \%$ probability.

\section{Results and Discussion}

\subsection{Phytochemical prospecting}

Phytochemical analysis of the ethanolic extract of the C. argyrophylloides leaves demonstrated the presence of phenols: flavone, flavonol and xanthone type. In addition to these, saponins and alkaloids were also found. These data can be seen in Table 1, in which the presence or absence of each analyzed metabolite was indicated by $\mathrm{P}$ or N, respectively. Phytochemical analysis of the species Euphorbia biumbellata, Euphorbia terracina and Euphorbia dendroides (family Euphorbiaceae) revealed the presence of several secondary metabolites in the aerial parts of the studied plants: tannins, flavonoids, lipids, sterols, saponins and terpenes. In contrast, the alkaloids were not detected (Zeghad et al., 2016).

The great interest around these classes of secondary metabolites is the correlation that these compounds have with various biological activities (Fonseca et al., 2019; Santos et al., 2018), such as antioxidant and antimicrobial activities among other (Silva et al., 2021; Kuhn et al., 2019; Mallmann et al., 2018). A diet abundant in some of these compounds is able to act in the prevention of various diseases. Compounds such as saponins are related to action detergent and emulsifier, expectorant and diuretic (Kaneshima et al., 2016), anti-inflammatory (Xiong et al., 2015), antifungical (Woldemichael and Wink, 2001).

The tannins have astringent, antidiarrheal drug effects, antimicrobial, antiseptic and the flavonoids, abundant in fruits, have anti-inflammatory properties, antibacterial, antifungal, antioxidant and anticâncer (Kaneshima et al., 2016).

The phytochemical profile of the leaves of C. argyrophylloides presented a result similar to the phytochemical study of the species in which the presence of alkaloids and 12 polyphenols were found in Croton heliotropiifolius Kunth (Randau et al., 2014); and alkaloids, steroids, flavonols, flavanones, tannins, triterpenoid and xanthones in Croton linearifolius Mull. arg. (Oliveira et al., 2014). According to Morais et al. (2016), the presence of flavones, flavonols and xanthones was found in the leaves of this caatinga species.

\subsection{Quantitative antioxidant evaluation by the DPPH method}

Regarding the quantitative assessment of antioxidant activity (AAO\%) by the DPPH method, it was possible to observe a significant bioactivity of 84.70 AAO\% in $500 \mu \mathrm{g} / \mathrm{mL}$ (Table 2). The antioxidant behavior of the vegetable sample was represented by the linear line equation model, with a determination coefficient $\left(R^{2}\right)$ greater than 0.9 , which enabled the determination of its effective concentration at $50 \%\left(\mathrm{EC}_{50}\right)$. The $\mathrm{EC}_{50}$ of the ethanolic extract of $C$. argyrophylloides was $236.79 \mu \mathrm{g} / \mathrm{mL}$.

This result can be related to the secondary metabolites detected in this plant sample through phytochemical screening (phobanic tannins, flavonols, xanthones, flavones, catechins, saponins and alkaloids). The research

Table 1. Prospection of the chemical constituents of C. argyrophylloides leaves.

\begin{tabular}{cc}
\hline Secondary metabolites & Results \\
\hline Phenols & $\mathrm{N}$ \\
Pyrogelic tannins & $\mathrm{N}$ \\
Flobafenic tannins & $\mathrm{P}$ \\
Anthocyanyn and anthocyanidin & $\mathrm{N}$ \\
Flavones, flavonols and xanthones & $\mathrm{P}$ \\
Chalcones and auronas & $\mathrm{N}$ \\
Flavonols & $\mathrm{N}$ \\
Leucoanthocyanidins & $\mathrm{N}$ \\
Catechins & $\mathrm{P}$ \\
Flavonones & $\mathrm{N}$ \\
Steroids & $\mathrm{P}$ \\
Triterpenoids & $\mathrm{N}$ \\
Saponins & $\mathrm{P}$ \\
Alkaloids & $\mathrm{P}$ \\
\hline
\end{tabular}

$(\mathrm{P})=$ Positive; $(\mathrm{N})=$ Negative.

Table 2. Evaluation of antioxidant activity through the hijacking of DPPH radical activity of leaves Croton argyrophylloides Muell. Arg.

\begin{tabular}{cc}
\hline $\begin{array}{c}\text { Concentrations } \\
\text { tested }(\mu \mathrm{g} / \mathrm{mL})\end{array}$ & AAO \% \\
\cline { 2 - 2 } 500 & DPPH (\%) \\
200 & 84.70 \\
150 & 40.53 \\
75 & 37.35 \\
50 & 32.90 \\
25 & 33.92 \\
12 & 22.87 \\
\hline
\end{tabular}


by Rath et al. (2011) showed a DPPH activity present in the aqueous extract of leaves of Croton roxyburgii Balaki of $50.75 \mu \mathrm{g} / \mathrm{mL}$. Melo et al. (2011), analyzed other species of Euphorbiaceae, such as Croton blanchetianus Baill and Jatropha mollissima (Pohl) Baill, finding an $\mathrm{EC}_{50}$ of 94.0 and $55.0 \mu \mathrm{g} / \mathrm{mL}$, respectively, these results were lower comparing to this study. The values of $\mathrm{R}^{2}$ of standard, leaves and barks were $0.935,0.841$ and 0.979 , respectively, indicating the existence of a strong, linear and positive relationship between DPPH concentration and activity in leaves and bark extract and extract respectively.

In Basto (2014) study the elimination activity increased upon increasing concentrations of Croton nummularius Baill oil, reaching $76.16 \%$ at $5 \mathrm{mg} / \mathrm{mL}$ and presenting a calculated $\mathrm{EC}_{50}$ value of $62.52 \mathrm{mg} / \mathrm{mL}$, these results were higher than in the present study. The elimination activity of peroxide radicals of $C$. nummularius' essential oil increased in a dose-dependent manner. The essential oil extracted from the species of Croton tetradenius Baillon showed an $\mathrm{EC}_{50}$ value corresponding to $2.49 \mathrm{mg} \cdot \mathrm{mL}^{-1}$, $\mathrm{R}^{2}$ 0.9991). The BHT positive control showed an $\mathrm{EC}_{50}$ value corresponding to $0.61 \mathrm{mg} \cdot \mathrm{mL}^{-1}, \mathrm{R}^{2} 0.9776$ (Fernandes, 2016).

\subsection{Phenolics compounds determination}

After statistical processing in a Microsoft Excell ${ }^{\circledR}$ program, the line equation and the $\mathrm{R}^{2}$ determination coefficient higher than 0.9 were determined as the gallic acid calibration curve. Through the interpolation of the absorbances, of the sample, on the calibration curve it was possible to determine the content of total phenolic compounds found in the research, which was $946.06 \mathrm{mg}$ EAG/g sample, which proves the result presented by the phytochemical and antioxidant study. The phenolic compounds were determined with the Folin-Ciocalteau phenol reagent and the total phenol content was determined for plant species using the same methodology. The species $C$. roxyburgii studied by Rath et al. (2011) presented contents of 2.3 and $0.3 \mathrm{mg}$ of gallic acid/g for bagasse and concentrated crude extract, respectively). These results had a lower concentration than those presented by the ethanolic extract of this research. For Silva et al. (2012), the concentration of total phenols, demonstrated a significant result, measured in mg of gallic acid equivalent per gram of sample with 323.95 having +/- 1.36 standard deviation, whereas in Kanumfre et al. (2017) the value obtained for the species Croton antisyphiliticus Martius was $113.9 \pm 1.49$ (mg EAG/g), both respectively lower than the present study. In studies on plant extracts, there are statistical correlations between the content of total polyphenols measured by the Folin-Ciocalteu method and antioxidant activity determined by the DPPH test, showing the importance of these secondary metabolites for antioxidant activity (Gontijo et al., 2014).

\subsection{Quantitative determination of flavonoids}

After statistical treatment in the Microsoft Excel ${ }^{\circledR}$ program, the line equation and the determination coefficient $\left(\mathrm{R}^{2}\right)$ greater than 0.9 for the quercetin calibration curve was determined. Through the line equation it was possible to determine the value of total flavonoids in the sample, of 58.11 equivalents of quercetin/g of the sample, presented a superior result when compared to the species Euphorbia drummondii Boiss ( $0.51 \pm 0.12 \mathrm{mg}$ ECAT/g) for the crude ethanolic extract (Gulati et al., 2012).

The result is also superior to that found in the ethanol extract from the bark of the species Croton argyrophyllus Kunth, which had a total flavonoid content of the extract of $1467 \pm 264 \mu \mathrm{g}$ equivalent in quercetin/g of the sample (Costa et al., 2017). Kanumfre et al. (2017) found results of $22.6 \pm 0.74$ equivalents of quercetin from the sample of Croton antisyphiliticus Martius finding values lower than the ones from this study. Using the aluminum chloride method, after reading the absorbances, the values were interpolated against the calibration curve in Microsoft Office Excel ${ }^{\circledR}$, to determine the equation of the line, the coefficient of determination $\left(R^{2}\right)$ which was 0.995 for the calibration of quercetin.

\subsection{ABTS free radical capture test [2,2-azino-bis (3-ethylbenzotazolin) -6-sulfonic]}

In the study by Araújo et al. (2014) the antioxidant capacity of the Euphorbia tirucalli L.'s dry extract was evaluated using the ABTS method and detected a value of Trolox Equivalent Antioxidant Capacity (TEAC) in a sample of $718 \mu \mathrm{M}$ Trolox/g (Table 3 ), these values were lower than those found in C. argyrophylloides expressed in $219716.66 \mu$ Mol Trolox/g. While Rockenbach et al. (2007), when evaluating the ethanol extract of Vitis vinifera, it identified $477 \mu \mathrm{M}$ Trolox/g antioxidant activity and Silva (2017) obtained $1704 \mu \mathrm{M}$ Trolox/g in the hydroalcoholic extract of the mountain guava leaf. In view of the results described in the literature, it is evident that the evaluated extract, in the present work, showed greater efficiency in the capture of the ABTS cation.

\subsection{Ferric reducing antioxidant power - FRAP}

The result of antioxidant activity by iron reducing was calculated from the straight line equation obtained by the standard trolox curve, whose $\mathrm{R}^{2}$ was also greater than 0.9 . From the equation of the straight line obtained in the graph of the standard curve with a correlation coefficient of 0.99 , it was possible to quantify the concentration of $\mathrm{Fe}^{2+}$ present in solution. For the FRAP methodology, the Trolox values were applied to the equation of the line to obtain the $\mathrm{R}^{2}$, which was 0.99 . The result obtained from the FRAP method, presented a value of $15294.44 \mu \mathrm{M}$ Trolox/g of the sample (Table 3 ).

The result of the quantitative evaluation of the antioxidant activity of Croton argyrophyllus Kunth extract, performed by Costa et al. (2017) by the FRAP method was $167.87 \pm 2.88 \mu \mathrm{M}$ Trolox/g of the sample. Júnior et al. (2016),

Table 3. Evaluation of antioxidant activity through FRAP and ABTS of leaves Croton argyrophylloides Muell. Arg.

\begin{tabular}{ccc}
\hline $\begin{array}{c}\text { Concentrations } \\
\text { tested }(\mathbf{m g} / \mathbf{m L})\end{array}$ & FRAP & ABTS \\
\hline \multirow{2}{*}{$2 \mathrm{mg} / \mathrm{mL}$} & $15294,44 \mu \mathrm{M}$ & $219716.66 \mu \mathrm{M}$ \\
& Trolox $/ \mathrm{g}$ & Trolox $/ \mathrm{g}$ \\
\hline
\end{tabular}


detected the capacity of Croton campestris A. St. Hill the value of the iron reduction potential of the extract was $131 \mu \mathrm{M}$ Fe II/0.1g.

According to Oliveira (2015) in order to characterize a compound as an antioxidant, such activity should not be based on a single methodology, requiring the application of other methods, such as FRAP (Ferric Reducing Ability of Plasma). Thus, the evaluation of the antioxidant activity of the extract was also made by the FRAP method, with the antioxidant capacity being measured through the emergence of a dark blue color in the solutions, produced after the reduction of the iron $\mathrm{Fe}^{+3}$ to $\mathrm{Fe}^{+2}$, due to the presence of antioxidant compounds in the evaluated samples. Therefore, the higher the antioxidant potential of the compounds present in the samples, the higher the production of $\mathrm{Fe}^{+2}$ ions in the solution.

\subsection{Antibacterial evaluation}

According to the results found, the extract behaves differently upon the tested microorganisms. The activity of the crude extract towards the strain of S. aureus ATCC 25923 presented growth inhibition halos of 10 and $12 \mathrm{~mm}$ in diameter, in which one of the halos did not grow, and there was no activity towards the E. coli ATCC 25922 and P. aeruginosa ATCC 27853, with no halos formed.

Antibacterial analysis of the species Euphorbia macroclada, Euphorbia denticulata and Euphorbia virgata (family Euphorbiaceae) showed that the extracts of $E$. macroclada have antibacterial activity as 8-23 $\mathrm{mm}$ zone of inhibition against the tested microorganisms, this extract demonstrated the highest flavonoid content and all tested showed a very high antioxidant activity. Different from what was observed in our study, the extract of $E$. denticulata did not show any activity against $E$. coli. extract of E. cheiradenia showed inhibitory effect against the test microorganisms (8-13 and 9-14 mm inhibition zone) (Kirbag et al., 2013). The mentioned researchers claimed that sensitivity of microorganism to chemoterapeutic compounds can change even against different strains. The antimicrobial activities of different Euphorbia species are changeable according to other research findings (Sudhakar et al., 2006; Ogbulie et al., 2007; Barla et al., 2007). Further research is necessary to determine the identitity of the antibacterial compounds isolated from $C$. argyrophylloides and also to determine their full spectrum of efficacy (Parekh and Chanda, 2007).

The presence of activity on Gram positive bacteria (S. aureus) extract and absence of activity on Gram negative bacteria ( $E$. coli and $P$. aeruginosa) is in accordance with current scientific knowledge, which report higher sensitivity of the first one concerning plant metabolites (Ferreira et al., 2010). The double membrane presented by many Gram-negative bacteria throughout the body; lower risk of side effects, due to the low concentrations in which the active ingredients are present in plants, not considering dose-time correlations; lower research costs when compared to the development of a new drug (Yunes et al., 2001).

This research revealed several secondary metabolites present in the species. These groups of compounds may be responsible for many of the reported therapeutic properties attributed to the plant. The ethanolic extract of the leaves of $C$. argyrophylloides showed an efficient antioxidant activity through the DPPH tests, in addition to demonstrating a significant result of the content of phenolic compounds and the content of total flavonoids. The significant antioxidant activity exhibited by the species C. argyrophylloides explains the higher concentration of phenolic substances, among them the flavonoids, known for their efficient free radical scavenging action. This makes it a promising species in the development of research aimed at preventing diseases related to oxidative stress. The inhibitory activity of this plant could be due to presence of polyphenols and flavonoids in large quantity, which have been widely reported as antimicrobial agentes (Coppo and Marchese, 2014).

The results showed the importance of evaluating an antioxidant activity by different methods, as it is not possible to state which methodology is better applicable than the other, since they all have their own characteristics that are related, enabling a broader assessment of the samples when conjunctly done. It is also noteworthy that the present study identified an expressive antioxidant potential in the leaves of the vegetable, an analysis that may serve as a basis for future studies that seek new natural sources of compounds with this property. Finally, the results obtained in the antibacterial activity tests showed that $C$. argyrophylloides exhibited activity in vitro upon the strain of $S$. aureus ATCC 25923. The other strains P. aeruginosa ATCC 27853 and E. coli ATCC 25922 did not exhibit the studied antimicrobial activity upon the extract. In similar studies, the extract of various plants inhibited the growth of some microorganisms at different rations. Different plants possess different constituents in different concentrations, which account for differential antimicrobial effect as also suggested (Alonso et al., 2020; Yihune and Yemata, 2019; Bereksi et al., 2018).

\section{Conclusion}

It is evident from the present study that the $C$. argyrophylloides extract could be utilized as a good natural source of antioxidants and a possible food supplement or as an antimicrobial agent in pharmaceutical industry. The present study of in vitro antimicrobial evaluation $C$. argyrophylloides forms a primary platform for further pharmacological studies to discover new antibiotic drugs.

\section{References}

ALAM, M.N., BRISTI, N.J. and RAFIQUZZAMAN, M., 2013. Review on in vivo and in vitro methods evaluation of antioxidant activity. Saudi Pharmaceutical Journal, vol. 21, no. 2, pp. 143-152. http:// dx.doi.org/10.1016/j.jsps.2012.05.002. PMid:24936134.

ALONSO, M.M., SALAZAR, J.C.L., ROBLES, S.O., GUERREIRO, I.C., GARCÍA, F.L. and MARRERO, J.G., 2020. In vitro antimicrobial activity of mexican plants on bovine mastitis bacteria: preliminary studies. Bioscience Journal, vol. 36, no. 1, pp. 183190. http://dx.doi.org/10.14393/BJ-v36n1a2020-42137.

ARAÚJO, K.M., LIMA, A., SILVA, J.N., RODRIGUES, L.L., AMORIM, A.G., QUELEMES, P.V., SANTOS, R.C., ROCHA, J.A., ANDRADES, 
É.O., LEITE, J.R., MANCINI-FILHO, J. and TRINDADE, R.A., 2014. Identification of phenolic compounds and evaluation of antioxidant and antimicrobial properties of Euphorbia Tirucalli L. Antioxidants, vol. 3, no. 1, pp. 159-175. http://dx.doi.org/10.3390/ antiox3010159. PMid:26784670.

BARLA, A., ÖZTÜRK, M., KÜLTÜR, Ş. and ÖKSÜZ, S., 2007. Screening of antioxidant activity of three Euphorbia species from Turkey. Fitoterapia, vol. 78, no. 6, pp. 423-425. http://dx.doi.org/10.1016/j. fitote.2007.02.021. PMid:17582698.

BASTO, S.R.M., 2014. Croton nummularius Baill. (Euphorbiaceae): composição química, atividade biológica, antioxidante e toxicidade preliminar dos óleos essenciais. Recife: Universidade federal de Pernambuco, 46 p. Dissertação de Mestrado em Bioquímica e Fisiologia.

BEREKSI, M.S., HASSAÏNE, H., BEKHECHI, C. and ABDELOUAHID, D.E., 2018. Evaluation of antibacterial activity of some medicinal plants extracts commonly used in Algerian traditional medicine against some pathogenic bacteria. pharmacognosy Journal, vol. 10, no. 3, pp. 507-512. http://dx.doi.org/10.5530/pj.2018.3.83.

BERRY, P.E., HIPP, A.L., WURDACK, K.J., VAN EE, B. and RIINA, R., 2005. Molecular phylogenetics of the giant genus Croton and tribe Crotoneae (Euphorbiaceae sensu stricto) using ITS and trnL-trnF sequence data. American Journal of Botany, vol. 92, no. 9, pp. 1520-1534. http://dx.doi.org/10.3732/ajb.92.9.1520. PMid:21646170.

BRAND-WILLIANS, W., CUVELIER, M.E. and BERSET, C., 1990. Use of free radical method evaluate oxidante activity. LebensmittelWissenschaft und -Technologie, vol. 28, pp. 25-30.

CATÃO, R.M.R., BARBOSA-FILHO, J.M., LIMA, E.O., PEREIRA, M.S.V., SILVA, M.A.R., ARRUDA, T.A. and ANTUNES, R.M.P., 2010. Avaliação da atividade antimicrobiana e efeitos biológicos de riparinas sobre eliminação de resistência a drogas em amostras de Staphylococcus aureus. Revista Brasileira de Análises Clinicas, vol. 42, no. 1, pp. 9-14.

COPPO, E. and MARCHESE, A., 2014. Antibacterial activity of polyphenols. Current Pharmaceutical Biotechnology, vol. 15, no. 4, pp. 380-390. http://dx.doi.org/10.2174/1389201015041 40825121142. PMid:25312620.

COSTA, M.A.R., SANTOS, R.R.C., GUALBERTO, S.A. and CUNHA E SILVA, S.L., 2017. Fenólicos totais, flavonoides totais e atividade antioxidante de extratos de Croton argyrophyllus Kunth (Euphorbiaceae). Enciclopédia Biosfera, vol. 14, no. 25, pp.687701. http://dx.doi.org/10.18677/EnciBio_2017A53.

CRAMER, L.H. and COLEUS, R.W., 2016. Atividade antimicrobiana de extratos de Plectranthus grandis (L. H. Cramer) R. Willemse (Boldo) e Aloe vera (Linnaues) Burm (Babosa) sobre Escherichia coli e Staphylococcus aureus. Revista Biociências, vol. 22, no. 1, pp. 39-47.

FERNANDES, D.N.M., 2016. Composição química, atividade antimicrobiana e antioxidante do óleo essencial de Croton tetradenius Baill (Euphorbiaceae). Itapetinga: Universidade Estadual do Sudoeste da Bahia, 74 p. Dissertação de Mestrado em Ciências Ambientais.

FERREIRA, S.B., PALMEIRA, J.D., SOUZA, J.H., ALMEIDA, J.M., FIGUEIREDO, M.C.P., PEQUENO, A.S., ARRUDA, T.A., ANTUNES, R.M.P. and CATÃO, R.M.R., 2010. Avaliação da Atividade Antimicrobiana in vitro do extrato hidroalcóolico de Stryphnodendron adstringens (Mart.) Coville sobre isolados ambulatoriais de Staphylococcus aureus. Revista Brasileira de Análises Clínicas, vol. 42, no. 1, pp. 27-31.

FLOEGEL, A., KIM, D.O., CHUNG, S.J., KOO, S.I. and CHUN, O.K., 2011. Comparison of ABTS/DPPH assays to measure antioxidant capacity in popular antioxidant-rich US foods. Journal of Food
Composition and Analysis, vol. 24, no. 7, pp. 1043-1048. http:// dx.doi.org/10.1016/j.jfca.2011.01.008.

FONSECA, S.A., COSTA, J.R.M., GOMES, N.R.S., CUNHA, A.L., COSTA, J.G., MATOS-ROCHA, T.J., SILVA, K.W.L., FRANÇA, P.H.B., SILVA JÚNIOR, F.F., SANT'ANA, A.E.G. and SANTOS, A.F., 2019. Antioxidant and cicatrizing activity of the species Abarema cochliacarpos (Gomes) Barneby J. W. Grimes. African Journal of Pharmacy and Pharmacology, vol. 13, no. 14, pp. 170-180. http://dx.doi.org/10.5897/AJPP2019.4996.

GONTIJO, D.C., FIETTO, L.C. and LEITE, J.P.V., 2014. Avaliação fitoquímica e atividade antioxidante e, antimutagênica e toxicológica do extrato aquoso das folhas de Ocimum gratissimum L. Revista Brasileira de Plantas Medicinais, vol. 16, no. 4, pp. 874880. http://dx.doi.org/10.1590/1983-084X/12_002.

GULATI, V., HARDING, I.H. and PALOMBO, E.A., 2012. Enzyme inhibitory and antioxidant activities of traditional medicinal plants: potential application in the management of hyperglycemia. BMC Complementary and Alternative Medicine, vol. 12, no. 1, pp. 77. http://dx.doi.org/10.1186/1472-6882-1277. PMid:22713130.

HALLIWELL, B. and GUTTERIDGE, J.M.C., 2015. Free radicals in Biology and medicine. New York: Oxford University Press. http://dx.doi. org/10.1093/acprof:oso/9780198717478.001.0001.

JÚNIOR, F.E., MACEDO, G.E., ZEMOLIN, A.P., SILVA, G.F., CRUZ, L.C., BOLIGON, A.A., DE MENEZES, I.R., FRANCO, J.L. and POSSER, T., 2016. Oxidant effects and toxicity of Croton campestris in Drosophila melanogaster. Journal of Pharmaceutical Biology, vol. 54, no. 12, pp. 3068-3077. http://dx.doi.org/10.1080/1388020 9.2016.1207089. PMid:27417881.

KANESHIMA, A.M.S., KANESHIMA, E.N., CAVALCANT, A.V. and WIDERSKI, K., 2016. Estudo terapêutico e geoecológico do Stryphnodendron adstringens (mart.) Coville: uma revisão integrativa. Revista Conhecimento e Sociedade, vol. 1, no. 1, pp. $\mathrm{X}-\mathrm{Xx}$.

KANUMFRE, F., RUANI, A.P., QUEIROZ, G.S., BRIGHENTE, I.M.C. and PIZZOLATT, M.G., 2017 [viewed 15 April 2020]. Avaliação da atividade antioxidante de Croton antisyphiliticus Martius. In: Anais da 34ํㅡㄹ Reunião Anual da Sociedade Brasileira de Química [online], 2017, Florianópolis. São Paulo: SBQ. Available from: http://sec.sbq.org.br/cdrom/34ra/resumos/T1562-1.pdf

KIRBAG, S., ERECEVIT, P., ZENGIN, F. and GUVENC, A. N., 2013. Antimicrobial activities of some Euphorbia species. Afr J Tradit Complement Altern Med., vol. 10, pp. 305-309.

KUHN, D., ZIEM, R., SCHEIBEL, T., BUHL, B., VETTORELLO, G., PACHECO, L.A., HEIDRICH, D., KAUFFMANN, C., FREITAS, E.M., ETHUR, E.M. and HOEHNE, L., 2019. Antibiofilm activity of the essential oil of Campomanesia aurea O. Berg against microorganisms causing food borne diseases. Food Science and Technology, vol. 108, pp. 247-252. http://dx.doi.org/10.1016/j. lwt.2019.03.079.

MALLMANN, R., ETHUR, E.M., BIANCHETTI, P., FALEIRO, D., HOEHNE, L. and GOETTERT, M.I., 2018. Effectiveness of aqueous and hydroalcoholic extracts of Acanthospermum australe (Loefl.) Kuntze against diarrhea-inducing bactéria. Brazilian Journal of Biology = Revista Brasileira de Biologia, vol. 78, no. 4, pp. 619-624. http://dx.doi.org/10.1590/1519-6984.167376. PMid:29319752.

MATOS, F.J.A., 1997. Introdução à fitoquímica experimental. 2. ed. Fortaleza: Edições UFC.

MELO, J.G., SANTOS, A.G., AMORIM, E.L., DO NASCIMENTO, S.C. and ALBUQUERQUE, U.P., 2011. Medicinal plants used as antitumor agents in Brazil: an ethnobotanical approach. Evidence-Based Complementary and Alternative Medicine, vol. 2011, pp. 1-14. http://dx.doi.org/10.1155/2011/365359. PMid:21528006. 
MENSOR, L.L., MENEZES, F.S., LEITÃO, G.G., REIS, A.S., SANTOS, T.C., COUBE, C.S. and LEITÃO, S.G., 2001. Screening of Brazilian plant extracts for antioxidant activity by the use of DPPH free radical method. Phytotherapy Research, vol. 15, no. 2, pp. 127-130. http://dx.doi.org/10.1002/ptr.687. PMid:11268111.

MORAIS, N.R.L., OLIVEIRA NETO, F.B., MELO, A.R., BERTINI, L.M., SILVA, F.F.M. and ALVES, L.A., 2016. Prospecção fitoquímica e avaliação do potencial antioxidante de Cnidoscolus phyllacanthus (müll. Arg.) Pax \& k.hoffm. Oriundo de apodi - RN. Revista Brasileira de Plantas Medicinais, vol. 18, no. 1, pp. 180-185. http://dx.doi. org/10.1590/1983-084X/15_058.

OGBULIE, J.N., OGUEKE, C.C., OKOLI, I.C. and ANYANWU, B.N., 2007. Antibacterial activities and toxicological potantials of crude ethanolic extracts of Euphorbia hirta. African Journal of Biotechnology, vol. 6, pp. 1544-1548.

OLIVEIRA, G.P., CUNHA E SILVA, S.L., GUALBERTO, S.A., CRUZ, R.C.D. and CARVALHO, K.S., 2014. Atividade larvicida do extrato etanólico da raiz de Croton linearifolius sobre Aedes aegypti. Enciclopédia Biosfera, vol. 10, no. 18, pp. 442.

OLIVEIRA, G.L.S., 2015. Determinação da capacidade antioxidante de produtos naturais in vitro pelo método do $\mathrm{DPPH} \bullet$ : estudo de revisão. Rev. Bras. Pl. Med., Campinas, vol. 17, pp. 36-44.

PAREKH, J. and CHANDA, S.V., 2007. In vitro antimicrobial activity and phytochemical analysis some indian medicinal plants. Turkish Journal of Biology, vol. 31, pp. 53-58.

PORTO, R.S., 2010. Ação do óleo essencial de Croton argyrophylloides muell. arg. e de um dos seus constituintes o $\beta$-cariofileno em músculo liso fásico de rato. Fortaleza: Universidade Federal do Ceará, 105 p. Dissertação de Mestrado em Ciências Fisiológicas.

RANDAU, K.P., FLORÊNCIO, D.C., FERREIRA, C.P. and XAVIER, H.S., 2014. Estudo Farmacognóstico de Croton rhamnifolius H.B.K. e Croton rhamnifolioides pax \& hoffm. (Euphorbiaceae). Revista Brasileira de Farmacognosia, vol. 14, no. 2, pp. 89-96. http:// dx.doi.org/10.1590/S0102-695X2004000200001.

RATH, S., PATRA, J.K., MOHAPATRA, N., MOHANTY, G., DUTTA, S. and THATOI, H., 2011. In vitro antibacterial and antioxidant studies of Croton roxburghii. L., from similipal Biophere reserve. Indian Journal of Microbiology, vol. 51, no. 3, pp. 363-368. http://dx.doi. org/10.1007/s12088-011-0133-2. PMid:22754018.

ROCKENBACH, I.I., SILVA, G.L., RODRIGUES, E., GONZAGA, L.V. and FETT, R., 2007. Atividade antioxidante de extratos de bagaço de uma das variedades Regete e Pinot Noir (Vitis vinífera). Revista do Instituto Adolfo Lutz, vol. 66, no. 2, pp. 158-163.

RUFINO, M.S.M., ALVES, R.E., BRITO, E.S., MORAIS, S.M., SAMPAIO, C.G., PÉREZ-JIMÉNEZ, J. and SAURA-CALIXTO, F.D., 2006. Determinação da atividade antioxidante total em frutas pelo método de redução do ferro (FRAP). Fortaleza: Embrapa Agroindústria Tropical, 4 p. Comunicado Técnico, no. 125.

SÁNCHEZ, M.C., 2002. Review: methods used to evaluate the free radical scavenging activity. Foods and Biological Systems, vol. 1, no. 1, pp. 121-137.

SANTOS, A.F., PAVÃO, J.M.S., ROCHA, T.J.M., SOUZA, M.A., ALVES, H.H.F. and OLIVEIRA, H.C.A., 2018. Análise da produção científica sobre plantas com potencial antioxidante, antimicrobiano e alelopático disponíveis na base Scielo. Diversitas Journal, vol. 3, no. 2, pp. 375-394. http://dx.doi.org/10.17648/diversitasjournal-v3i2.645.

SCHERER, R. and GODOY, H.T., 2014. Effects of extraction methods of phenolic compounds from Xanthium strumarium L. and their antioxidant activity. Revista Brasileira de Plantas Medicinais, vol. 16, no. 1, pp. 41-46. http://dx.doi.org/10.1590/S151605722014000100006 .
SEHWAG, S. and DAS, M., 2014. Antioxidant activity: an overview. Journal of Food Science and Technology, vol. 2013, pp. 1-10.

SILVA, A.P.S., 2017. Avaliação do potencial antioxidante dos extratos da folha da goiaba-serrana (Acca sellowiana (O Berg.) Burret). Florianópolis: Universidade Federal de Santa Catarina, 46 p. Trabalho de Conclusão de Curso em Engenharia de Alimentos.

SILVA, F.R.G., MATIAS, T.M.S., SOUZA, L.I.O., MATOS-ROCHA, T.J., FONSECA, S.A., MOUSINHO, K.C. and SANTOS, A.F., 2019. Phytochemical screening and in vitro antibacterial, antifungal, antioxidant and antitumor activities of the red propolis Alagoas. Brazilian Journal of Biology = Revista Brasileira de Biologia, vol. 79, no. 3, pp. 452-459. http://dx.doi.org/10.1590/1519-6984.182959. PMid:30379200.

SILVA, K.B., PINHEIRO, C.T.S., SOARES, C.R.M., SOUZA, M.A., MATOSROCHA, T.J., FONSECA, S.A., PAVÃO, J.M.S.J., COSTA, J.G., PIRES, L.L.S. and SANTOS, A.F., 2021. Phytochemical characterization, antioxidant potential and antimicrobial activity of Averrhoa carambola L. (Oxalidaceae) against multiresistant pathogens. Brazilian Journal of Biology = Revista Brasileira de Biologia, vol. 81, no. 3, pp. 509-515. http://dx.doi.org/10.1590/1519-6984.220259. PMid:32876163.

SILVA, L.A., RAPOSO, J.D.A., CAMPOS, L.P.G., CONCEIÇÃO, E.C., OLIVEIRA, R.B. and MOURÃO, R.H.V., 2018. Atividade antioxidante do óleo essencial de Myrcia sylvotica (G. Mey) DC. por diferentes métodos de análises antioxidantes (ABTS, DPPH, FRAP, $\beta$-caroteno/ácido linoleico). Revista Fitos, vol. 12, no. 2 , pp. 117-126. http://dx.doi.org/10.5935/2446-4775.20180011.

SILVA, M.J.D., ENDO, L.H., DIAS, A.L.T., SILVA, G.A., SANTOS, M.H. and SILVA, M.A., 2012. Avaliação da atividade antioxidante e antimicrobiana dos extratos e frações orgânicas de Mimosa caesalpiniiflia Benth. (Mimosaceae). Revista de Ciências Farmacêuticas Básica e Aplicada, vol. 33, no. 2, pp. 267-274.

SILVA, T.S. and FREIRE, E.M.X., 2010. Abordagem etnobotânica sobre plantas medicinais citadas por populações do entorno de uma unidade de conservação da caatinga do Rio Grande do Norte, Brasil. Revista Brasileira de Plantas Medicinais, vol. 12, no. 4, pp. 427-435. http://dx.doi.org/10.1590/S1516-05722010000400005.

SPEISKY, H., LÓPEZ-ALARCÓN, C., GOMEZ, M., FUENTES, J. and SANDOVAL-ACUNA, C., 2012. First web-based database on total phenolics and oxygen radical absorbance capacity (ORAC) of fruits produced and consumed within the South Andes Region of South America. Journal of Agricultural and Food Chemistry, vol. 60, no. 36, pp. 8851-8859. http://dx.doi.org/10.1021/ jf205167k. PMid:22512599.

SUDHAKAR, M., RAO, C.H.V., RAO, P.M., RAJU, D.B. and VENKATESWARLU, Y., 2006. Antimicrobial activity of Caesalpinia pulcherrima, Euphorbia hirta and Asystasia gangeticum. Fitoterapia, vol. 77, no. 5, pp. 378-380. http://dx.doi.org/10.1016/j. fitote.2006.02.011. PMid:16730921.

WOLDEMICHAEL, G.M. and WINK, M., 2001. Identification and biological activities of triterpenoid saponins from Chenopodium quinoa. Journal of Agricultural and Food Chemistry, vol. 49, no. 5, pp. 2327-2332. http://dx.doi.org/10.1021/jf0013499. PMid:11368598.

XIONG, H., ZHENG, Y., YANG, G., WANG, H. and MEI, Z., 2015. Triterpene saponins with anti-inflammatory activity from the stems of Entada phaseoloides. Fitoterapia, vol. 103, pp. 33-45. http://dx.doi.org/10.1016/j.fitote.2015.03.001. PMid:25759122.

YIHUNE, E. and YEMATA, G., 2019. Antibacterial activity of medicinal plant extracts against Ralstonia solanacearum (Smith) that causes bacterial wilt in hot pepper (Capsicum annuum L.). Acta Scientiarum. Biological Sciences, vol. 41, no. 1, pp. e45402. http:// dx.doi.org/10.4025/actascibiolsci.v41i1.45402. 
YUNES, R.A., PEDROSA, R.C. and CECHINEL FILHO, V., 2001. Fármacos e fitoterápicos: a necessidade do desenvolvimento da indústria de fitoterápicos e fitofármacos no Brasil. Quimica Nova, vol. 4, no. 1, pp. 147-152. http://dx.doi.org/10.1590/S0100-40422001000100025.
ZEGHAD, F., DJILANI, S.E., DJILANI, A. and DICKO, A., 2016. Antimicrobial and antioxidant activities of three Euphorbia species. Turkish Journal of Pharmaceutical Sciences, vol. 13, no. 1, pp. 47-56. http://dx.doi.org/10.5505/tjps.2016.29491. 